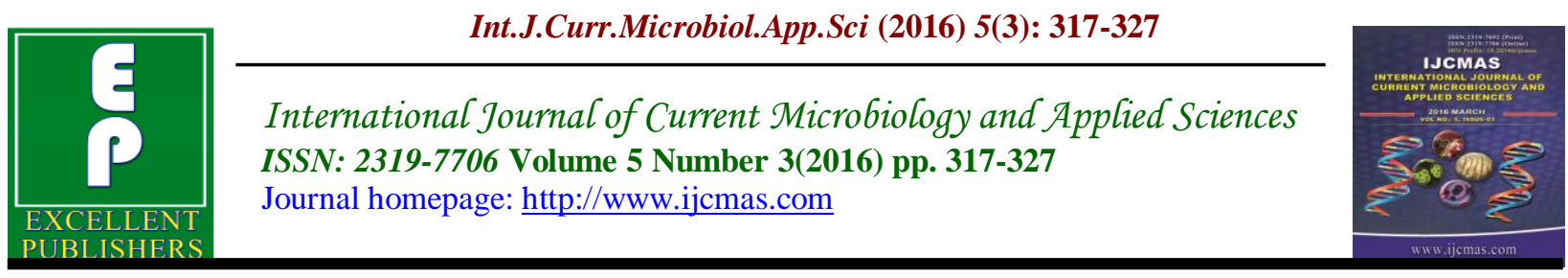

Original Research Article

http://dx.doi.org/10.20546/ijcmas.2016.503.039

\title{
Study of Genetic Diversity of Iraqi Date Palms Using Some Morphological Markers
}

\author{
Hussam S. M. Khierallah* and Hadeel D. Azhar \\ Date Palm Researches Unit, College of Agriculture, University of Baghdad, Iraq \\ *Corresponding author
}

\begin{abstract}
A B S T R A C T
Keywords

Phoenix

Dactylifera,

Genetic

Diversity,

Morphlogical

Markers,

PCA.

Article Info

Accepted:

15 February 2016

Available Online:

10, March 2016

In order to study the genetic diversity for a number of cultivars and ecotypes for Iraqi date palms (Phoenix dactylifera L.). Forty Iraqi well known cultivars from five different regions in Iraq were chosen. These including cultivars grown in some date palm stations belonging to the Ministry of Agriculture. The study included 14 morphological markers comprise trunk, leaf and fruits traits. Results indicated that the average number of alleles for all cultivars was 4.2. Shoot tip shape had seven alleles while fruit shield had only two. Major allele frequency ranged from 0.3 for fruit shape to 0.825 for fruit texture. Gene diversity was also ranged from 0.296 for fruit texture suggesting lowest polymorphism information content (PIC) value (0.265) to 0.771 for shoot tip shape suggesting highest polymorphism information content (PIC) value (0.742). Results of simple correlation among studied phenotypic traits reveled that highest correlation value reached 0.543 between the trunk size and leaf (fronds) length, followed by the correlation between trunk size and leaf base (0.540), while the lowest correlation was 0.012 between fruit stalk color and leaf base. Cluster analysis based on the Euclidean distances using UPGMA split selected cultivars into two main groups independently of their geographic regions with 6.9 Euclidean distance. The scatter diagram plot of the multivariate Principal component analysis (PCA) of the first two (PC1 and PC2) based on morphological markers revealed $31.86 \%$ of the variation among cultivars with Eigen value of 4.67 while PC2 was $17.93 \%$ with Eigen value of 4.63 . Results of PCA scatter diagram exhibit the same clusters as shown in the dendrogram.
\end{abstract}

\section{Introduction}

The date palm (Phoenix dactylifera L.) is one of the oldest cultivated fruit trees and was well-known in Babylon, Iraq 4000 B.C. The palms were celebrated during that period for their strength and majesty (Khierallah et al., 2015). Iraq remains one of the leading date producing countries in the world. Before 1991, it was the world's largest producer (FAO 2004) and had the most extensive date forest in the world, (MacFarquhar, 2003). However, a serious decline over the past 30 years occurred due to numerous military conflicts since the 1980s. During recent wars, large numbers of date palm trees were destroyed. Water quality became crucial due to the harmful 
effects of the wars which destroyed date palm orchards in various regions, but especially in Basrah governorate, Shatt AlArab region (Khierallah et al., 2015). The numbers of known date palm cultivars that are distributed all over the world may be as high as 3000 out of which about 630 are found in Iraq. Wars and economic sanctions imposed on Iraq have negatively affected both the production and natural genetic diversity of the crop and inhibited the much needed impetus to rebuild the date palm industry. The collection and genetic characterization of the all Iraqi cultivars using different genetic markers is one of the important goals in date palm rehabilitation efforts. During the last few years, the General Board of Date Palm, Ministry of Agriculture has collected over 510 date palm cultivars and planted them in 30 date palm stations dispersed in the south and middle parts of the country. Such a number of genotypes reflect the much-needed efforts to get powerful, accurate and practical genetic markers that can be used in a high resolution mapping for these cultivars. The success of any plant genetic conservation or breeding program depends on understanding the amount and distribution of the genetic variation present in the genetic pool. Morphological traits have been used to describe genetic variation in date palm cultivars, which are mainly related to the fruit, leaf, trunk and other parts of the tree. An early survey of Iraqi cultivars using morphological description was done by AlBaker (1962); he distinguished 531 cultivars and their origin, availability and fruit quality. Another morphological identification was done on 110 Iraqi cultivars by Al-Jboory (1971). In 1972, AlBaker again described 627 Iraqi cultivars in his celebrated book in Arabic, The Date Palm, adding some fruit traits to the earlier description. Three decades later, Husien (2002) and Husien and Greab (2004) also gave a brief description of 36 and 50 cultivars, respectively. Al-Saleh and AlAnsary (2005) adopted 12 phenotypic traits to describe 110 cultivars, documented with color photos. Thirty vegetative date palm descriptors were screened by Hammadi et al., (2009) in Tunisia. Al-Wusaibai et al., (2014) studied 11 representative cultivars from eastern, central and western region of Saudi Arabia Kingdom. Recently, Twenty Pakistani date palm cultivars from nine different geographical regions were characterized to estimate the polymorphism and possible similarity level (Naqvi et al., 2015). While Al-Asasfa et al. (2015) employed phenotypic traits to characterize and survey wild population of date palm in Jordan. The aim of this study is the use of morphological markers in assessing genetic diversity in some Iraqi date palm cultivars cultivated in five different regions.

\section{Materials and Methods}

Forty Iraqi well known cultivars from five different regions in Iraq were chosen (Fig 1). Those were grown in some date palm stations belonging to the Ministry of Agriculture. The study included 14 morphological markers (Table 2).

Trunk size, shoot tip shape, leaves (fronds) traits (leaf length, leaf base, leaf bending) and fruit traits (fruit shape, fruit size, fruit texture, fruit maturation, fruit color, fruit test, fruit shield, fruit stalk color and fruit stalk length) were estimated visually and maintained three replications (palms) per cultivar. As regards the fruit characters observations were recorded in 15 fruits per palm. Fruits color and test were estimated in khalal stage. Phenotypic traits were then transferred into 1, 2, 3 ...etc symbol form in order to be ready for data analysis (Table 2). 


\section{Data Analysis}

Major allele frequency, gene diversity and polymorphism information content (PIC) and genetic distance among the 40 cultivars were estimated using software Power Marker V3.25 (Liuand Muse, 2005). For the genetic similarity analysis, Jaccard's coefficient of similarity (Jaccard, 1908) was used. A dendrogram was generated by cluster analysis using the unweighted pair group method of the arithmetic averages (UPGMA). Simple correlation values among phenotypes and Principal Coordinated Analysis (PCA) was also carried out to show multiple dimension of the distribution of the accessions in a scatter-plot with variance percentage and Egine value for each component by PAST software version 1.62 (Hammer et al., 2001).

\section{Markers Parameters and Correlation}

Table 3 shows some of the parameters describing morphological markers used in the study. The average number of alleles for all cultivars was 4.2. Shoot tip shape had seven alleles while fruit shield had only two. Major allele frequency ranged from 0.300 for fruit shape to 0.825 for fruit texture. Gene diversity was also ranged from 0.296 for fruit texture suggesting lowest polymorphism information content (PIC) value $(0.265)$ to 0.771 for shoot tip shape suggesting highest polymorphism information content (PIC) value (0.742).

Shoot tip shape as well as fruit shape seem to be a powerful markers to distinguish date palm cultivars. The present study results are in agreement with Al- Khalifa et al. (2012) and Al-Wusaibai et al. (2014) for fruit shape of the cultivars Khalas and Sukari respectively.

Results shown in Table (4) indicated to simple correlation among studied phenotypic traits for the selected cultivars grown in five regions in Iraq. The highest correlation value reached 0.543 between the trunk size and leaf (fronds) length, followed by the correlation between trunk size and leaf base (0.540), while the lowest correlation was 0.012 between fruit stalk color and leaf base.

The study of the correlation between the phenotypic characteristics of the date palm has conducted by Naqvi et al. (2015) who found that there is a high correlation between the trunk size and the leaf length and base. As the trunk in the date palm is coated by the leaf base, it was reported that the size of the trunk is due to several factors, including the leaf base (Karab) cells enlargement as well as meristematic cells division and enlargement of the mantel meristem region of the palm shoot apex (Ibrahim, 2008).

\section{Cluster Analysis}

Results shown in Figure 2 indicates to the cluster analysis of the cultivars grown in five environmental areas using the UPGMA method for Euclidean distance depending on phenotypic traits.

Two main groups of cultivars was determined independently of their geographic regions with 6.9 Euclidean distance value, the first group was divided into two subgroups with 6.3 Euclidean distance first included: Behrab, Soltani, Saei, Khastawi Euphrates Hamrawi cultivars and the second included Ashrasi and Khiara cultivars with Euclidean distance of 4.85 , while the second main group divided into two subgroups with Euclidean distance of 5.7 Barhi was the first while the second devided into two subgroups with Euclidean distance 5.1. The first group included: Khatibi, Khadhrawi Basra 
Table.1 Names and Geographic Regions of Some Iraqi Date Palm Cultivars

\begin{tabular}{|c|c|c|c|c|c|}
\hline No. & Cultivars & $\begin{array}{c}\text { Geographic } \\
\text { region }\end{array}$ & No. & Cultivars & $\begin{array}{l}\text { Geographic } \\
\text { region }\end{array}$ \\
\hline 1 & Bream & South & 21 & Meer Haj & East \\
\hline 2 & Khadhrawi Basrah & 66 & 22 & Meer Ali & 66 \\
\hline 3 & Deari & 6 & 23 & ShelaniAhmer & 6" \\
\hline 4 & Barhee & “6 & 24 & QulHusieni & 6 \\
\hline 5 & Hasawi & “6 & 25 & UstaOmran & Center \\
\hline 6 & Sayer & “6 & 26 & Ashrasi & 6 \\
\hline 7 & Gentar & “6 & 27 & Dubaini & “6 \\
\hline 8 & Um Al-Dehn & “6 & 28 & Tebarzal & 6 \\
\hline 9 & Dakwani & West & 29 & Barban & 6 \\
\hline 10 & Tabarzal & “" & 30 & Qeetaz & "6 \\
\hline 11 & Khiarah & 6 & 31 & Zahdi Baghdad & 6 \\
\hline 12 & Khateebi & “6 & 32 & Khadhrawi Baghdad & “6 \\
\hline 13 & Qayari & “6 & 33 & Um Al-Blaleez & Euphrates \\
\hline 14 & Hamrawi & 66 & 34 & Siltani & 66 \\
\hline 15 & Saaee & 6 & 35 & Ibraheemi & 6 \\
\hline 16 & Zahdi West & “6 & 36 & Ouainat Aube & “6 \\
\hline 17 & $\begin{array}{l}\text { Khadhrawi } \\
\text { Mandili }\end{array}$ & East & 37 & Khastawi FM & ، \\
\hline 18 & Maktoom Asfar & “6 & 38 & Zahdi FM & 6 \\
\hline 19 & Behrab & 6 & 39 & Khadhrawi FM & 6 \\
\hline 20 & Qrenfeli & 6 & 40 & Khastawi Shthatha & 6" \\
\hline
\end{tabular}


Table.2 Characterization Table of Iraqi Dale Palm Cultivars Using Some Morphological Markers

\begin{tabular}{|c|c|c|c|c|c|c|c|}
\hline No. & Phenotype & Marker & Symbol & No. & Phenotype & Marker & Symbol \\
\hline \multirow[t]{5}{*}{1} & \multirow[t]{5}{*}{ Trunk size } & thin & 1 & \multirow[t]{5}{*}{8} & \multirow[t]{5}{*}{ Fruit texture } & soft & 1 \\
\hline & & thin-medium & 2 & & & semi dry & 2 \\
\hline & & medium & 3 & & & dry & 3 \\
\hline & & medium-thick & 4 & & & & \\
\hline & & thick & 5 & & & & \\
\hline \multirow[t]{5}{*}{2} & \multirow[t]{5}{*}{ Leaf length } & short & 1 & \multirow[t]{5}{*}{9} & \multirow{5}{*}{$\begin{array}{l}\text { Fruit } \\
\text { maturation }\end{array}$} & early & 1 \\
\hline & & short- medium & 2 & & & early-medium & 2 \\
\hline & & medium & 3 & & & medium & 3 \\
\hline & & medium- long & 4 & & & medium-late & 4 \\
\hline & & long & 5 & & & late & 5 \\
\hline \multirow[t]{5}{*}{3} & \multirow[t]{5}{*}{ Leaf base } & narrow & 1 & \multirow[t]{5}{*}{10} & \multirow{5}{*}{$\begin{array}{l}\text { Fruit } \\
\text { (khalal) } \\
\text { color }\end{array}$} & yellow & 1 \\
\hline & & narrow -medium & 2 & & & yellow-red & 2 \\
\hline & & medium & 3 & & & red & 3 \\
\hline & & medium- wide & 4 & & & & \\
\hline & & wide & 5 & & & & \\
\hline \multirow[t]{7}{*}{4} & \multirow{7}{*}{$\begin{array}{l}\text { Shoot tip } \\
\text { Shape }\end{array}$} & pyramidal small & 1 & \multirow[t]{7}{*}{11} & \multirow{7}{*}{$\begin{array}{l}\text { Fruit (khalal) } \\
\text { test }\end{array}$} & sweet & 1 \\
\hline & & pyramidal medium & 2 & & & medium & 2 \\
\hline & & pyramidal wide & 3 & & & bitter & 3 \\
\hline & & spheral small & 4 & & & & \\
\hline & & spheral medium & 5 & & & & \\
\hline & & spheral large & 6 & & & & \\
\hline & & interminable & 7 & & & & \\
\hline \multirow[t]{5}{*}{5} & \multirow[t]{5}{*}{ Leaf bending } & little erect & 1 & \multirow[t]{2}{*}{12} & \multirow[t]{2}{*}{ Fruit shield } & adherent & 1 \\
\hline & & medium erect & 2 & & & separated & 2 \\
\hline & & erect & 3 & \multirow[t]{8}{*}{13} & \multirow{8}{*}{$\begin{array}{l}\text { Fruit stalk } \\
\text { color }\end{array}$} & green & 1 \\
\hline & & Erect in sides & 4 & & & yellow-green & 2 \\
\hline & & level & & & & & \\
\hline \multirow[t]{5}{*}{6} & \multirow[t]{5}{*}{ Fruit shape } & oval & 1 & & & yellow & 3 \\
\hline & & interminable & 2 & & & \multirow[t]{4}{*}{ orang } & \multirow[t]{4}{*}{4} \\
\hline & & inverse & 3 & & & & \\
\hline & & cylindrical & 4 & & & & \\
\hline & & taper & 5 & & & & \\
\hline \multirow[t]{4}{*}{7} & Fruit size & small-medium & 1 & 14 & Fruit stalk & short & 1 \\
\hline & & medium & 2 & & lenght & medium & 2 \\
\hline & & medium-large & 3 & & & long & 3 \\
\hline & & large & 4 & & & & \\
\hline
\end{tabular}


Table.3 Number of Alleles, Major Allele Frequency, Gene Diversity and Polymorphism Information Content for Some Morphological Markers Used to Assess Genetic Diversity of Iraqi Date Palm Cultivars

\begin{tabular}{|l|l|c|c|c|c|}
\hline No. & $\begin{array}{c}\text { Morphological } \\
\text { Markers }\end{array}$ & $\begin{array}{c}\text { No. of } \\
\text { Alleles }\end{array}$ & $\begin{array}{c}\text { Major Allele } \\
\text { Frequency }\end{array}$ & $\begin{array}{c}\text { Gene } \\
\text { diversity }\end{array}$ & $\begin{array}{c}\text { Polymorphism } \\
\text { information } \\
\text { content (PIC) }\end{array}$ \\
\hline 1 & Trunk size & 5 & 0.564 & 0.629 & 0.593 \\
\hline 2 & Leaf length & 5 & 0.564 & 0.609 & 0.560 \\
\hline 3 & Leaf base & 5 & 0.744 & 0.419 & 0.389 \\
\hline 4 & Shoot tip shape & 7 & 0.385 & 0.771 & 0.742 \\
\hline 5 & Leaf bending & 5 & 0.400 & 0.738 & 0.698 \\
\hline 6 & Fruit shape & 5 & 0.300 & 0.754 & 0.710 \\
\hline 7 & Fruit size & 4 & 0.675 & 0.504 & 0.466 \\
\hline 8 & Fruit texture & 3 & 0.825 & 0.296 & 0.265 \\
\hline 9 & Fruit maturation & 5 & 0.450 & 0.705 & 0.662 \\
\hline 10 & Khalal color & 3 & 0.450 & 0.635 & 0.559 \\
\hline 11 & Khalal test & 3 & 0.725 & 0.436 & 0.395 \\
\hline 12 & Fruit shield & 2 & 0.745 & 0.381 & 0.309 \\
\hline 13 & Fruit stalk color & 4 & 0.525 & 0.636 & 0.584 \\
\hline 14 & Fruit stalk length & 3 & 0.564 & 0.579 & 0.509 \\
\hline & Average & 4.2 & 0.565 & 0.578 & 0.532 \\
\hline
\end{tabular}


Table.4 Simple Correlation Values Among Some Phenotypes for 40 Date Palm Cultivars Grown in Five Regions of Iraq

\begin{tabular}{|c|c|c|c|c|c|c|c|c|c|c|c|c|c|c|}
\hline & $\begin{array}{l}\text { Trunk } \\
\text { size }\end{array}$ & $\begin{array}{l}\text { Leaf } \\
\text { length }\end{array}$ & $\begin{array}{l}\text { Leaf } \\
\text { base }\end{array}$ & $\begin{array}{l}\text { Shoot } \\
\text { tip } \\
\text { shape }\end{array}$ & $\begin{array}{l}\text { Leaf } \\
\text { bending }\end{array}$ & $\begin{array}{l}\text { Fruit } \\
\text { shape }\end{array}$ & $\begin{array}{l}\text { Fruit } \\
\text { size }\end{array}$ & $\begin{array}{l}\text { Fruit } \\
\text { texture }\end{array}$ & $\begin{array}{l}\text { Fruit } \\
\text { maturation }\end{array}$ & $\begin{array}{l}\text { Khalal } \\
\text { color }\end{array}$ & $\begin{array}{l}\text { Khalal } \\
\text { test }\end{array}$ & $\begin{array}{l}\text { Fruit } \\
\text { shield }\end{array}$ & $\begin{array}{l}\text { Fruit } \\
\text { stalk } \\
\text { color }\end{array}$ & $\begin{array}{l}\text { Fruit } \\
\text { stalk } \\
\text { lenght }\end{array}$ \\
\hline Trunk size & 1.000 & & & & & & & & & & & & & \\
\hline Leaf length & 0.543 & 1.000 & & & & & & & & & & & & \\
\hline Leaf base & 0.540 & 0.522 & 1.000 & & & & & & & & & & & \\
\hline $\begin{array}{l}\text { Shoot tip } \\
\text { shape }\end{array}$ & 0.389 & 0.245 & 0.334 & 1.000 & & & & & & & & & & \\
\hline Leaf bending & 0.183 & 0.138 & -0.068 & 0.042 & 1.000 & & & & & & & & & \\
\hline Fruit shape & 0.229 & 0.305 & 0.101 & 0.161 & -0.130 & 1.000 & & & & & & & & \\
\hline Fruit size & 0.154 & 0.135 & 0.302 & -0.002 & 0.232 & 0.397 & 1.000 & & & & & & & \\
\hline Fruit texture & -0.094 & -0.107 & -0.125 & -0.147 & -0.155 & 0.282 & 0.080 & 1.000 & & & & & & \\
\hline $\begin{array}{l}\text { Fruit } \\
\text { maturation }\end{array}$ & 0.162 & 0.385 & 0.390 & 0.204 & -0.365 & 0.161 & 0.192 & 0.200 & 1.000 & & & & & \\
\hline Khalal color & -0.146 & -0.092 & -0.396 & 0.038 & 0.189 & 0.119 & 0.089 & -0.135 & -0.180 & 1.000 & & & & \\
\hline Khalal test & -0.140 & -0.192 & -0.134 & 0.211 & 0.025 & 0.031 & -0.158 & 0.094 & -0.083 & 0.275 & 1.000 & & & \\
\hline Fruit shield & 0.119 & 0.127 & 0.105 & 0.082 & -0.284 & 0.156 & 0.061 & -0.133 & 0.121 & -0.058 & 0.092 & 1.000 & & \\
\hline $\begin{array}{l}\text { Fruit stalk } \\
\text { color }\end{array}$ & 0.034 & -0.053 & 0.012 & -0.072 & -0.043 & 0.285 & 0.044 & 0.407 & -0.095 & -0.099 & 0.112 & 0.059 & 1.000 & \\
\hline $\begin{array}{l}\text { Fruit stalk } \\
\text { lenght }\end{array}$ & 0.042 & 0.420 & 0.290 & 0.164 & -0.092 & 0.285 & 0.268 & 0.088 & 0.219 & -0.200 & -0.227 & 0.116 & 0.051 & 1.000 \\
\hline
\end{tabular}


Table.5 Variance Percentage and Eigen Values for all Principle Component Analysis for Iraqi Date Palm Cultivars Depending On Morphological Markers

\begin{tabular}{ccc}
\hline PC & \% Variance & Eigen value \\
\hline 1 & 31.86 & 4.67 \\
\hline 2 & 17.93 & 2.63 \\
\hline 3 & 13.30 & 1.95 \\
\hline 4 & 10.03 & 1.47 \\
\hline 5 & 6.13 & 0.89 \\
\hline 6 & 4.57 & 0.67 \\
\hline 7 & 3.85 & 0.57 \\
\hline 8 & 3.39 & 0.497 \\
\hline 9 & 2.84 & 0.42 \\
\hline 10 & 2.13 & 0.31 \\
\hline 11 & 1.43 & 0.21 \\
\hline 12 & 1.23 & 0.18 \\
\hline 13 & 0.72 & 0.11 \\
\hline 14 & 0.59 & 0.09 \\
\hline
\end{tabular}

Figure.1 Iraq Map Illustrating the Five Major Regions of Date Palm Cultivation

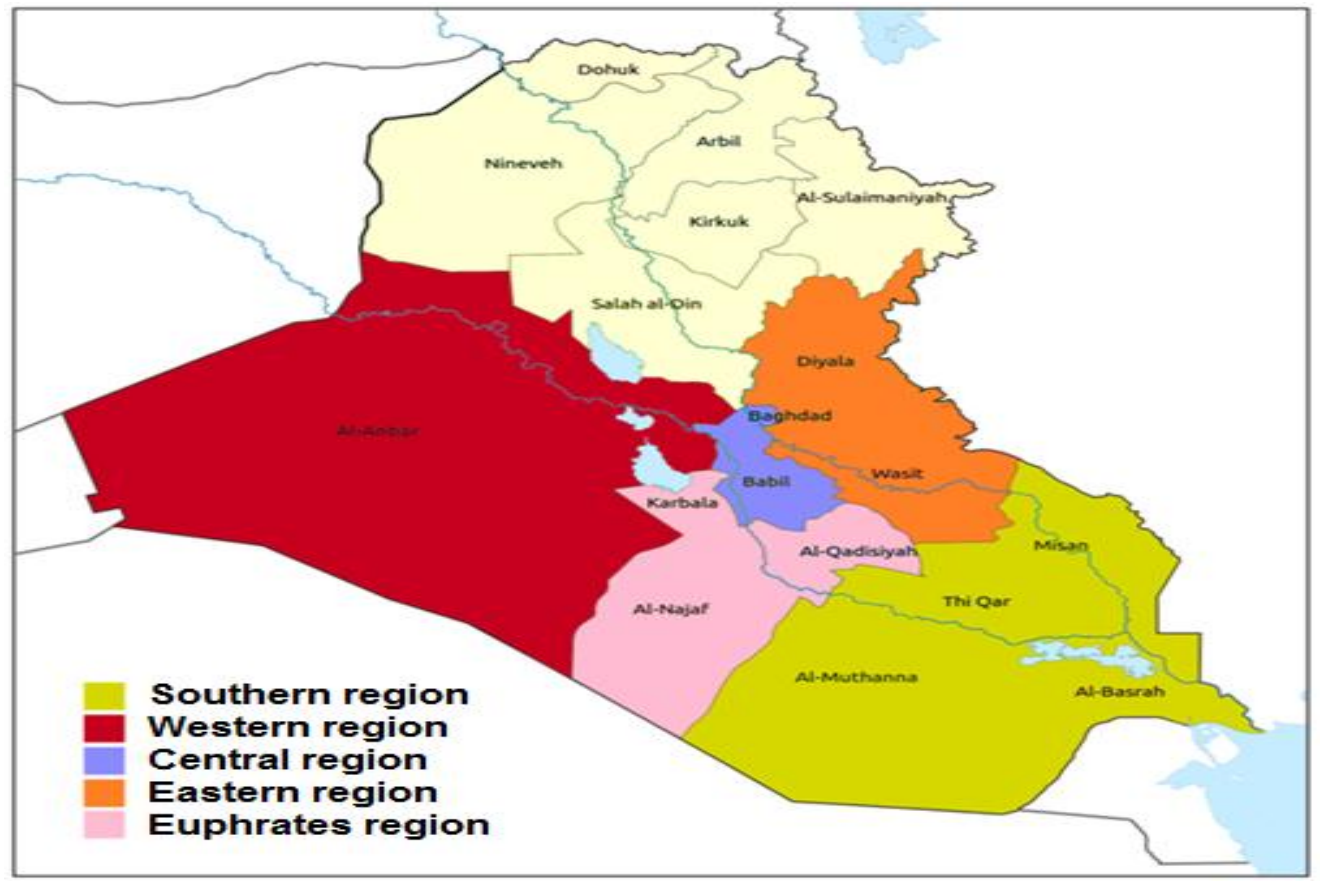


Figure.2 Cluster Analysis for Iraqi Date Palm Cultivars Depending on Morphological Markers

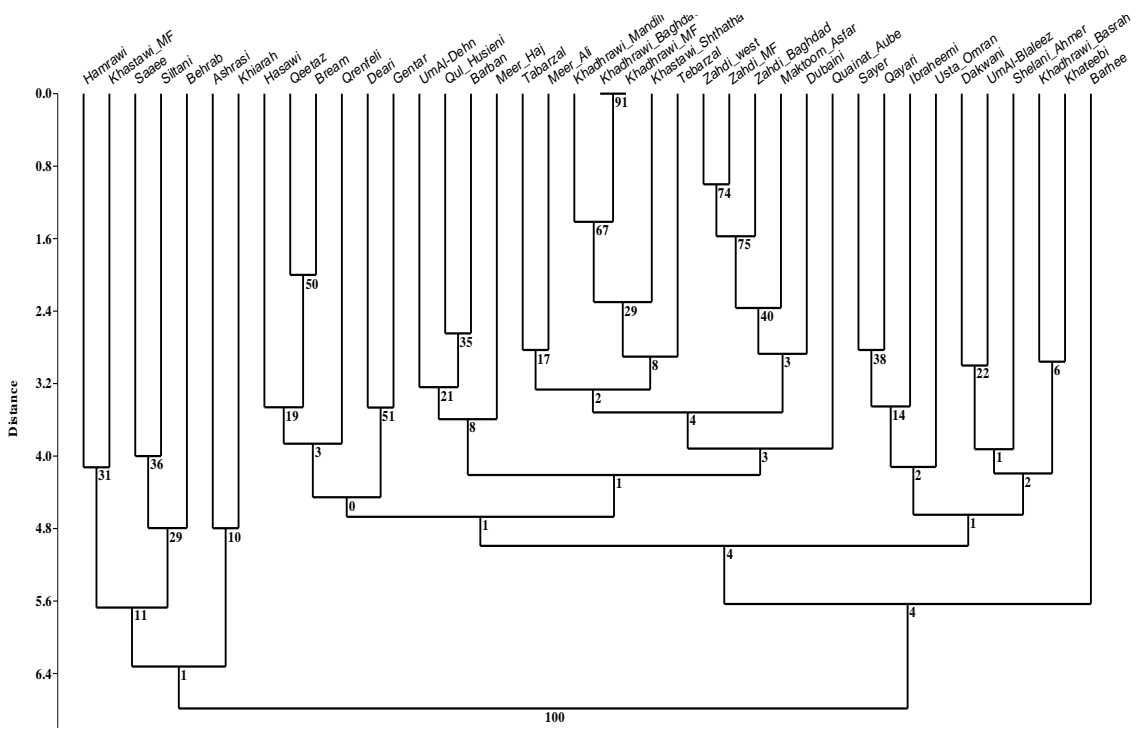

Figure.3 Scatter Diagram Plot of the First Two (Pc1 and Pc2) of Principle Component Analysis for Iraqi Date Palm Cultivars Depending on Morphological Markers

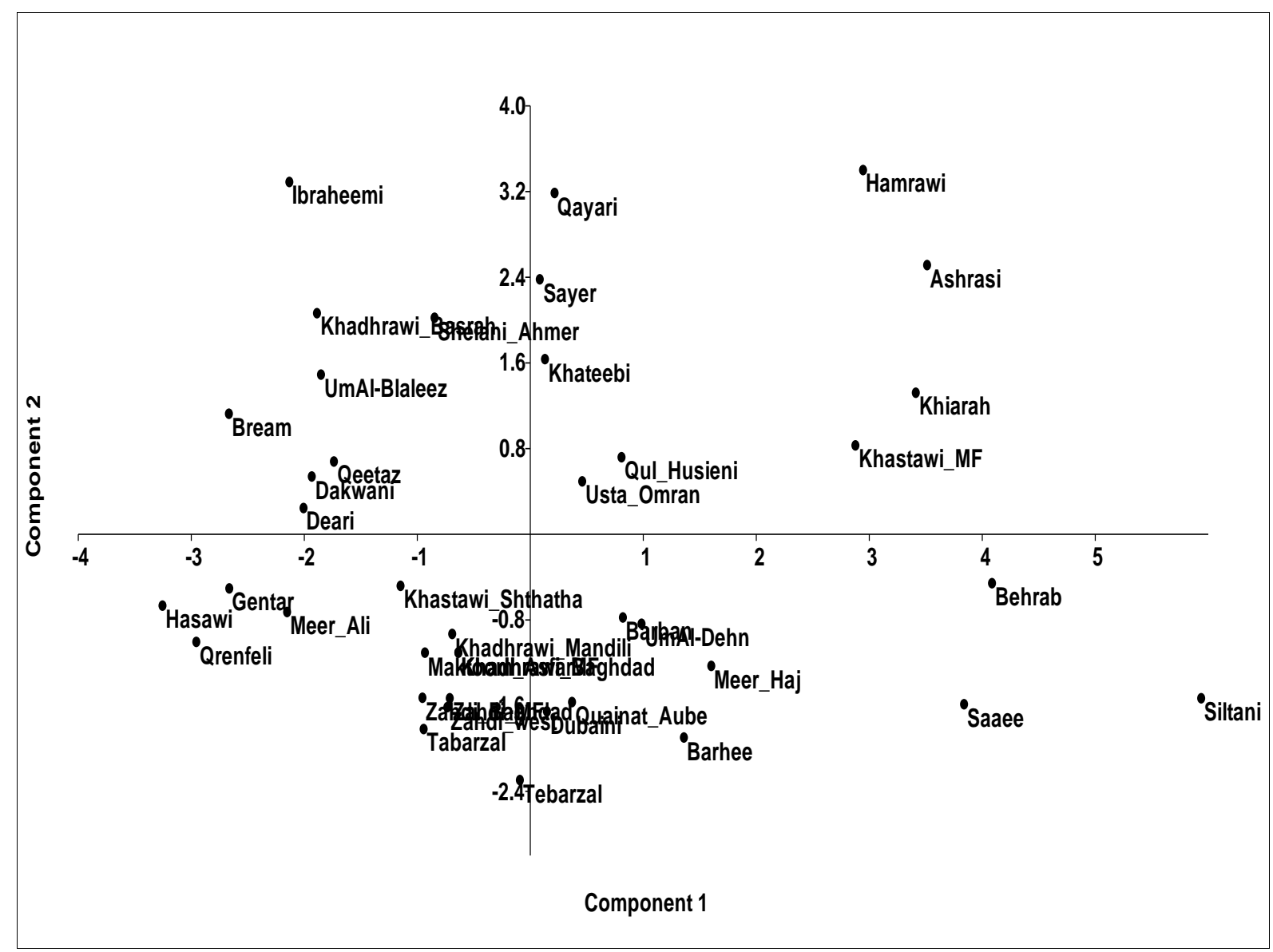


Shellaney Ahmer, Um Al-balaliz, Dakwani, Usta Imran, Ebrahimi, Qiari and Sayre. The second group included: Auient Ayoub, Dubeni, Maktom Asfar, Zahdi Middle, Zahdi Euphrates, Zahdi West, Tebrzal, Khastawi shithatha Khadhrawi Euphrates, Khadhrawi Baghdad, Khadhrawi Mandeli, Meer Ali, Tabrzel, Meer Haj, Burben, Qul Huseini, Um Al-Dhen, Quntar, Deri, Qurnfuli, Bream, Qitaz.

\section{Principal Component Analysis}

In order to confirm the results of cluster analysis describing genetic relationships among Iraqi date palm cultivars, data were analyzed by multivariate Principal Component Analysis (PCA) (Fig 3). The scatter diagram of the first two (PC1 and PC2) based on morphological markers revealed $31.86 \%$ of the variation among cultivars with Eigen value of 4.67 while PC2 was $17.93 \%$ with Eigen value of 4.63 . The rest components from 3 to 14 with its Eigen value is shown in Table 5. Results of PCA scatter diagram exhibit the same two clusters as shown in the dendrogram.

Consistent results of the present study with the findings of Al-Doss et al. (2001) in their study for 21 vegetative traits can be used to distinguish between the 17 cultivars of date palm in Saudi Arabia using cluster analysis and PCA analysis, and with what Mohammed et al. (2002) found when they use PCA analysis to distinguish between 26 Moroccan date palm cultivars. Our findings are also agreed with Al-Najjar (2014) through PCA analysis of 38 phenotypic vegetative traits to distinguish between 40 Iraqi male cultivars which gave $19.20 \%$ variance in the first component. Determination of phenotypic characteristic of date palm cultivars is an important step genetically and taxonomically. Great importance in recent studies that currently trending to identify the genes responsible for these traits, scientists and researchers working in universities and global research centers currently doing intensive efforts using genomics tools such as Genome Wide Association Studies (GWAS) to identify the genes responsible for the most important phenotypic traits of the date palm.

It can be concluded that there exists wide variability among Iraqi date palm cultivars studied and further molecular analysis will help to determine the relationship among these cultivars forming the basis to classify date palm cultivars in Iraq into clusters based on the above traits.

\section{References}

Al-Asasfa, M.A., Duwayri, M.A., Qasem, J.R., Al-Abdallat, M. 2015. Characterization and assessment of genetic diversity of wild date palm (Phoenix dactylifera L.) in Jordan. Jordan J. Agri. Sci., 11(1): 75-94.

Al-Baker, A.J. 1962. The Iraqi dates varieties. The Government Press, Iraq (in Arabic).

Al-Baker, A.J. 1972. The date palm: a review of its past and present status, and the recent advances in its culture, industry and trade. Al-Ani Press, Iraq (In Arabic).

Al- Doss, A.A., Ali, M.A., Bashah, M.A. 2001. Morphlogical variations for some date palm cultivars grown in Saudi Arabia. King Saud. Univ. J., 13: 3-18.

Al-Jboory, N.M., Khalaf, Z., Numan, V. 1971. A description of 110 Iraqi dates palm cultivars. Bull 38. General Horticulture Directorate, Ministry of Agriculture, Iraq (in Arabic).

Al-Khalifah, N.S., EjazAskari, Shanavas, Khan, A.E. 2012. Molecular and morphological identification of some elite varieties of date palms grown in Saudi Arabia, Emirates. J. Food Agri., 24(5): 456-461.

Al-Najaar, M.A. 2014. Classification and evaluation study for some date palm 
(Phoenix dactylifera L. ) male cultivars grown in middle and south of Iraq. $\mathrm{PhD}$. Dissertation, College of Agriculture, University of Basra, Iraq.

Al-Salih, A.A., Al-Ansary, N.A. 2005. Apictorial for Iraqi date palm cultivars. Part 1. Ministry of Agriculture. Al-Ezza Press, Baghdad, Iraq.

Al-Wusaibai , N., Abdallah B., Al-Husseini, M., Al-Hajji H., Al-Salman, H. Kurshed, K., Oihabi, A., El-Bellaj, M. 2014. Morphological characterization of Saudi Arabian date palm cultivars based on vegetative and reproductive traits. Proc. Fifth Int. Conf. Date Palm, Abu Dhabi, UAE, 57-64.

Food and Agriculture Organization (FAO). 2004. Food and Agriculture Organization Statistical data base (FAO STAT), Food Agr. org. of the United Nations, Rome. 24 May 2004. www.faostatfao.org.

Hammadi, H., Mokhtar, R., Mokhtar E., Ali, A. 2009. New approach for the morphological identification of date palm (Phoenix dactylifera L.) cultivars from Tunisia. Pak. J. Bot., 41(6): 2671-2681.

Hammer, Ø., Harper, D.A.T., Ryan, P.D. 2001. PAST: Palaeontological statistics software package for education and data analysis. Palaeontol. Electronica., 4: 19.

Husien, F.A. 2002. A Description of some Iraqi dates palm cultivars. Ministry of Agriculture, Iraq. (in Arabic).

Husien, F.A., Hraib, S.H. 2004. A description of 50 Iraqi dates palm cultivars. Ministry of Agriculture, Iraq (in Arabic).
Ibrahim, A.O. 2008. Date palm the tree of life. Arab Center for the Study of Arid Zones and Dry Lands (ACSAD), Damascus, Syria.

Jaccard, P. 1908. Nouvel le srescherchessur la distribution florale. Bulletin de la Socie1'te' vaudoise des sciences naturelles. 44: 223-270.

Khierallah, S.M., Bader, S.M., Ibrahim, K.M., Al-Jboory, I. J. 2015. Date Palm Status and Perspective in Iraq Chapter $4 \mathrm{In}$ : J.M. Al-Khayri et al. (eds.), Date Palm Genetic Resources, Cultivar Assessment, Cultivation Practices and Novel Products, (C) Springer Science+Business Media 2015.

Liu, K., Muse, S.V. 2005. PowerMarker: Integrated analysis environment for genetic marker data. Bioinfo., 21: 21282129.

MacFarquhar, N. 2003. Forbidden fruit: Iraq dates hit by war and sanctions. 2010. http://www.iht.com/ articles/83194.html. Food and Agriculture Organization of the United Nations. Accessed 1 July 2008.

Mohammed, A.E., Mohamed, S., Abdella, O., Christian, C. 2002. Phenotypic diversity of date palm cultivars (Phoenix dactylifera L.) from Morocco. Genet. Resour. Crop Ev., 49: 483-490.

Naqvi, S.A., Khan, I.A., Pintaud, J.C., Jaskani, M.J., Ali, A. 2015. Morphological characterization of Pakistani date Palm (Phoenix dactylifera L.) genotypes. Pak. J. Agri. Sci., 52(3): 645-650.

\section{How to cite this article:}

Hussam S. M. Khierallah and Hadeel D. Azhar. 2016. Study of Genetic Diversity of Iraqi Date Palms Using Some Morphological Markers. Int.J.Curr.Microbiol.App.Sci. 5(3): 317-327. doi: http://dx.doi.org/10.20546/ijcmas.2016.503.039 